\title{
An Exploratory Assessment of FSC Chain of Custody Certification Benefits in Croatian Wood Industry
}

\section{Određivanje koristi od certifikacije FSC lanca sljedivosti u hrvatskoj drvnoj industriji}

Original scientific paper • Izvorni znanstveni rad

Received-prispjelo: 24. 11. 2015.

Accepted-prihvaćeno: 5. 5. 2016.

UDK: $630 * 79$

doi:10.5552/drind.2016.1540

\begin{abstract}
Croatian State Forest Enterprise covers more than seventy five percent of forest area in the Republic of Croatia and it is the biggest supplier of Croatian wood industry companies. From the year of national forests FSC certification (2002) onwards, the number of issued FSC CoC certificates has exceeded two hundred. The increase of issued FSC certificates confirms that CoC certification has become a very important segment of the Croatian wood industry. In this research, the survey among Croatian FSC CoC certificate holders has been conducted. The aim of the research was to determine the reasons of implementing FSC CoC certification, benefits of certification and problems arising out of implementation. The research has shown that the respondents were forced to implement FSC CoC by the request from their customers. Furthermore, respondents stated that the most important benefit from FSC CoC implementation was to keep the existing customers and for the largest part of respondents the main problem in FSC CoC implementation was related to high certification costs. Regarding the financial benefits of FSC CoC certification for respondents, the results showed small, but significant positive correlation between certification duration and efficiency of total equity, as well as between certification duration and return on assets.
\end{abstract}

Key words: forest certification schemes, the Republic of Croatia, wood industry, benefits of certification, FSC ${ }^{\circledR}$, $\mathrm{CoC}$

SAŽETAK • Hrvatske šume d.o.o. pokrivaju više od $75 \%$ šumskog područja Republike Hrvatske i najveći su dobavljač sirovine za hrvatsku drvnu industriju. Od godine FSC certifikacije državnih šuma (2002.) do danas broj izdanih FSC CoC certifikata veći je od dvije stotine. Povećanje broja izdanih certifikata potvrđuje da je CoC certifikacija postala vrlo važna sastavnica poslovanja hrvatske drvne industrije. U sklopu ovog istraživanja provedena je anketa među hrvatskim nositeljima FSC CoC certifikata, a cilj istraživanja bio je odrediti razloge implementacije FSC CoC certifikacije, koristi od certifikacije i probleme koji nastaju pri implementaciji tog certifikata.

\footnotetext{
${ }^{1}$ Authors are as listed postdoctoral researcher, assistant professor, postdoctoral researcher, and master of wood technology at University of Zagreb, Faculty of Forestry, Wood Technology Department, Zagreb, Republic of Croatia. ${ }^{2}$ Author is associate professor at Technical University in Zvolen, Faculty of Wood Sciences and Technology, Zvolen, Republic of Slovakia. ${ }^{3}$ Author is assistant professor at University of Ljubljana, Biotechnical Faculty, Wood Technology Department, Ljubljana, Republic of Slovenia.

Autori su, redom, poslijedoktorandica, docent, poslijedoktorand i magistar drvne tehnologije Drvnotehnološkog odsjeka Šumarskog fakulteta, Sveučilište u Zagrebu, Zagreb, Republika Hrvatska. ${ }^{2}$ Autor je izvanredni profesor Fakulteta znanosti o drvu i drvne tehnologije, Tehničko sveučilište u Zvolenu, Zvolen, Republika Slovačka. ${ }^{3}$ Autor je docent Biotehničkog fakulteta, Sveučilište u Ljubljani, Ljubljana, Republika Slovenija.
} 
Rezultati su pokazali da je implementacija FSC CoC certifikacije u ispitanika najčešće potaknuta zahtjevima njihovih kupaca. Nadalje, najčešće isticana korist od FSC CoC implementacije jest zadržavanje postojećih kupaca, a za najveći dio ispitanika glavni su problem FSC CoC implementacije visoki troškovi tog postupka. S obzirom na financijske koristi od FSC CoC certifikacije za ispitanike, rezultati su pokazali malu, ali pozitivnu korelaciju između trajanja certifikacije i ekonomičnosti cjelokupnog poslovanja, kao i između trajanja certifikacije i njezina utjecaja na povrat imovine.

Ključne riječi: certifikacijske sheme šuma, Republika Hrvatska, drvna industrija, koristi od certifikacije, FSC ${ }^{\circledR}$, $\mathrm{CoC}$

\section{INTRODUCTION}

\section{UVOD}

Forest certification has been growing steadily in the last twenty years. After the Earth summit held in 1992 at Rio de Janeiro, Brazil, United Nations Conference on Environment and Development (UNCED) and the first global agreement concerning sustainability of forest management called the Statement of Forest Principles, forest certification began to develop more rapidly (Perera and Vlosky, 2006). In the next few years, as a reaction to the summit, the following forest certification schemes were established: FSC - Forest Stewardship Council (in 1993); SFI - Sustainable Forestry Initiative (in 1995); CSA - Canadian Sustainability Association Sustainable Forestry Management System (in 1996); PEFC - Programme for the Endorsement of Forest Certification (in 1999) (Ozinga, 2004). Today, the two largest international forest certification schemes in Europe and in the world are Forest Stewardship Council (FSC) and Programme for the Endorsement Forest Certification schemes (PEFC). There are two types of certificates: certificate for forest management (FM) and certificate for chain of custody (CoC). Currently, 272 million hectares of forest area are under the PEFC certification scheme (PEFC, 2015b) and 188 million hectares under the FSC certification scheme (FSC, 2016), which is more than $11 \%$ of the total global forest area (according to Forest Products Annual Market Review 20142015 the total global forest area is 4.033 billion hectares). Regarding $\mathrm{CoC}$ certificates, 30137 companies are the FSC CoC certificate holders (FSC, 2016) and 10744 companies are the PEFC CoC certificate holders (PEFC, 2015b). CoC certification is applicable to all organizations that trade, process or manufacture wood based and non-timber forest products. The FSC CoC certification is applicable to all $\mathrm{CoC}$ operations: trading, processing or manufacturing wood based and non-timber forest products from virgin and/or reclaimed materials including the primary industry sector (harvesting, pre-processing) or, in the case of recycled materials, reclamation sites, the secondary sector (primary and secondary manufacturing), and the tertiary sector (trading, wholesale, retail, print services) (FSC-STD-40-004 V2-1, 2011). Certified forest area has grown from 18 million ha in 2000 to over 430 million ha in 2014, and it has increased by more than twenty times (FAO, 2015). Almost $90 \%$ of global certificated area is in Northern Hemisphere (Fernholtz et al., 2015). According to UNECE/FAO's Forests Products Annual Market Review (2015), the number of CoC certificates of the two major certification schemes - FSC and PEFC, is steadily increasing. As forests cover almost one third of the earth's land surface, it is necessary to ensure sustainable forest management if global sustainable development is to come true (Paluš and Kaputa, 2009). The market is more and more oriented towards quality of products (Pirc Barčić and Motik, 2013), environmental projects, demands for a restructuration of wood industry in accordance with environmental needs (Lipušček et al., 2010; Oblak and Jošt, 2011). The world's largest furniture retailer - IKEA has been a member of FSC since 1993 and IKEA's long-term goal is to source all wood from forests certified as responsibly managed (IKEA, 2015).

Croatian State Forest Enterprise (Hrvatske šume d.o.o.) covers more than $75 \%$ of forest area in the Republic of Croatia (Hrvatske šume, 2015) and it is the biggest supplier of Croatian wood industry companies. Since 2002, Croatian State Forest Enterprise has been a FSC certificate holder. Therefore, Croatian wood industry sector companies got the chance to enter into the chain of custody. Constant growth of the number of FSC CoC certificates indicates that the Croatian wood industry has followed certification market trends. From the year of certification of national forests, the number of FSC CoC certificates has exceeded two hundred certificates (FSC, 2015). Only four PEFC CoC certificates are issued in the Republic of Croatia and those companies are engaged in trading with or belong to paper industry (PEFCa, 2015).

\section{LITERATURE REVIEW \\ 2. PREGLED LITERATURE}

Since forest products certification market has grown rapidly, the need has emerged of understanding benefits, reasons and problems of certification as an important direction of research. Forest certification has brought many positive changes in forest management (Moore et al., 2012). According to Rickenbach and Overdevest (2006), there are three views/perspectives of forest certification: market-based view; signal view and learning organization view. The first perspective sees certification effectiveness in direct market benefits price premiums and market share. Signal view holds that certification operates as a signal that the company applies high ecological standards to all stakeholders - buyers, governmental and non-governmental organizations. The third view sees certification as a tool for improving forest practices and production through learning.

Numerous studies have attempted to determine whether the certification brings any benefit and why certificate holders decided to implement chain of custody 
standards (Rickenbach and Overdevest, 2006; Vlosky et al., 2009; Bowers et al., 2012; Narasimhan et al., 2015). Vlosky et al. (2009) investigated changes in perception of wood-product manufacturers about certification in US from 2002 to 2008. Understanding of CoC certification has significantly increased from 2002 to 2008 . Business owner commitment to environment is the highest ranked reason for getting involved in certification by US certificate holders. Rickenbach and Overdevest (2006) came to quite similar results, showing that FSC certificate holders from US have made their decision to become certified to provide cue/signal to all external stakeholders that they apply higher level standards in forest practice. From the above studies, it can be seen that environmental awareness is very important for US certificate holders. Recent research results showed that intangible benefits of $\mathrm{CoC}$ certification - support to sustainable forestry and responsibility goals were also the highest ranked reasons among Chinese and Vietnamese FSC CoC certificate holders (Bowers et al., 2012). Price premium and market-based benefits from certification were among the lowest ranked reasons (Rickenbach and Overdevest, 2006; Bowers et al., 2012). On the other hand, Montague's study (2010) has shown that many companies pursue certification because of their customers and in order to achieve market advantage. Vidal et al. (2003) stated that the benefits associated with $\mathrm{CoC}$ certification may be long term and indirect. Nowadays, customers are willing to pay higher prices for certificated products (Kozak et al., 2004; Hoang et al., 2015). Therefore, FSC certification provides economic benefits in the form of higher prices (Newsom, 2008). The reasons CoC certification has not been adopted among Malaysian furniture manufacturers are as follows: lack of price premiums, limited market potential and high costs (Ratnasingam, 2009). Narasimhan et al. (2015) researched the impact of FSC certification on company's performance depending on company's position in the supply chain. They confirmed that the FSC certification brings more market benefits (measured via sales growth) to downstream companies - those closer to the end customer.

Chain of custody certification has become very important for wood industry of the Republic of Croatia. As no systematic researches have been conducted in this area, need has emerged to make research among chain of custody certificate holders of the Republic of Croatia. The objective of this study is presented through the following research questions:

(1) What are the main reasons for the implementation of FSC certification?

(2) What are the benefits of FSC certification?

(3) What are the main problems in implementing FSC certification?

(4) Does FSC certification bring financial benefits?

\section{METHODS}

\section{METODE}

For collecting data about FSC CoC certification, a survey method was used (Dillman, 2000). The survey was carried out among companies from the Republic of Croatia that hold FSC certificate. These companies were, therefore, placed in FSC Certificate Holder database (www.info.fsc.org). Companies certified under FSC certification scheme were chosen because almost all certificates are FSC (99\%). Later in the text, the term certification is referred to FSC CoC certification. In order to gather data from FSC certificate holders, Google Docs online questionnaire has been designed. The questionnaire was sent to all FSC certificate holders of the Republic of Croatia via a link embedded within an e-mail. The questionnaire consisted of two parts with a total of nineteen questions. The first part of the questionnaire contained general questions about the company. The second part referred to FSC certification, reasons for the implementation of FSC certification, gained benefits of certification, problems with the implementation of FSC certification and other questions concerning FSC certification. The survey with a cover letter was sent to $221 \mathrm{FSC}$ certificate holder from the Republic of Croatia and resulted with $23.5 \%$ response rate. Financial reports (income statement and balance sheet for 2014), needed for calculating profitability ratios, were obtained from the Registry of Financial Reports (RGFI, 2015). The research was conducted during June and July of 2015. Data were analysed using descriptive statistics, $\chi^{2}$-test and Pearson correlation by the use of STATISTICA 12 for MS Windows software (Dell Inc., 2015).

\section{RESULTS}

4. REZULTATI

\subsection{Profile of respondents}

\subsection{Profil ispitanika}

General characteristics of companies that participated in this research are shown in Table 1. The largest proportion of respondents are limited liability companies $(65.4 \%)$ and, according to the number of employees, they are micro and small companies (56.0\%).

The majority of respondents $(96.2 \%)$ sell their products outside the Republic of Croatia, mostly to the countries of the European Union (85\%). Italy, Germany, Austria and Slovenia were the most frequently stated $(65 \%)$ as the target market countries.

More than half of the surveyed FSC certificate holders $(56.3 \%)$ are engaged in wood processing and only $6.3 \%$ are furniture manufacturing companies (Table 1). Table 2 presents certified product groups by FSC product classification (FSC-STD-40-004a V2-0, 2011). It can be seen from Table 2 that FSC certificate holders from the Republic of Croatia are mostly certified for primary wooden products. The largest number of companies are certified for sawn wood (W5 = $72.9 \%$ ) and wood in chips or particles (W3 = 64.6\%).

\subsection{Reasons, benefits and problems of certification \\ 4.2. Razlozi, dobiti i problemi certifikacije}

One of the goals of research questions was to establish the main reasons of implementation of FSC certification (Table 3). The most important reason for in- 
Table 1 Profile of respondents

Tablica 1. Profil ispitanika

\begin{tabular}{|l|l|c|}
\hline \multirow{2}{*}{ Characteristics / Obilježja } & \multicolumn{1}{|c|}{ Description / Opis } & \multicolumn{1}{c|}{$\begin{array}{c}\text { Percent } \\
\text { Postotak }\end{array}$} \\
\hline \multirow{3}{*}{$\begin{array}{l}\text { Legal form } \\
\text { pravni oblik }\end{array}$} & company limited by shares / dioničko društvo - d.d. & $11.5 \%$ \\
\hline \multirow{4}{*}{$\begin{array}{l}\text { Number of employees } \\
\text { broj zaposlenika }\end{array}$} & limited liability company / društvo s ograničenom odgovornošću - d.o.o. & $65.4 \%$ \\
\cline { 2 - 3 } & craft / obrt & $23.1 \%$ \\
\cline { 2 - 3 } & less than 10 / do 10 & $20.0 \%$ \\
\cline { 2 - 3 } & from 11 to 50 / od 11 do 50 & $36.0 \%$ \\
\cline { 2 - 3 } & from 51 to 100 / od 51 do 100 101 to 150 / od 101 do 150 & $22.0 \%$ \\
\cline { 2 - 3 } $\begin{array}{l}\text { Basic activity } \\
\text { osnovna djelatnost }\end{array}$ & more than 151 / više od 151 & $10.0 \%$ \\
\cline { 2 - 3 } & furniture manufacturing / proizvodnja namještaja & $12.0 \%$ \\
\cline { 2 - 3 } & trade / trgovina & $56.3 \%$ \\
\cline { 2 - 3 } & production of paper / proizvodnja papira & $6.3 \%$ \\
\cline { 2 - 3 } & printing / tiskarska industrija & $20.8 \%$ \\
\cline { 2 - 3 } & other / ostalo & $2.1 \%$ \\
\hline
\end{tabular}

troducing FSC certification is that it was requested by their customers $(92.3 \%)$. This was followed by market demand $(63.5 \%)$, which means that a large number of companies surrounding the respondents had provided certification, so they decided to implement certification in order to stay competitive. More than half of respondents indicated the image of the company $(51.9 \%)$ and environmental awareness of FSC CoC certificate holders $(42.3 \%)$ as the reasons for the implementation of FSC certification. These results show that FSC certificate holders have made the decision regarding FSC certification mostly on request from their customers. They have not recognized FSC certificate as an instrument of promotion, and only $19.2 \%$ of respondents indicated that the reason for FSC implementation was company's promotion. Only $50 \%$ of respondents uses FSC trademarks for promotional purposes. Results indicate that for Croatian FSC certificate holders, implementation of FSC certificate is just one of the ways to survive in the market. In the last three years, there were no governmental subsidies for the implementation of FSC certification. The last subsidy program of the Government of the Republic of Croatia for certification of products was issued in 2013. None of the respondents noted the governmental subsidies as the reason for FSC implementation.

Benefits of implementation of FSC certification were also examined (Table 4). Keeping the existing customers is the main benefit of FSC certification for the largest number of respondents $(80.8 \%)$. As other benefits of FSC certification, respondents stated obtaining new customers $(59.6 \%)$, increase of competitiveness $(50.0 \%)$, increase of export $(34.6 \%)$ and increase of company's image $(32.7 \%)$. Increase of profit and increase of sales were the lowest ranked benefits of FSC certification. Low ranking of financial benefits are in correspondence with the results of Rickenbach and Overdevest (2006). Only $11.5 \%$ of

Table 2 Certified products by product groups $(N=52)$

Tablica 2. Proizvodne skupine certificiranih proizvoda $(N=52)$

\begin{tabular}{|c|c|c|}
\hline Product groups / Proizvodne skupine & $\begin{array}{l}\text { Number of answers } \\
\text { Broj odgovora }\end{array}$ & $\begin{array}{l}\text { Percent of answers } \\
\text { Postotak odgovora }\end{array}$ \\
\hline W1 - Rough wood / oblo drvo & 27 & $56.3 \%$ \\
\hline W2 - Wood charcoal / drvni ugljen & 1 & $2.1 \%$ \\
\hline W3 - Wood in chips or particles / usitnjeno drvo & 31 & $64.6 \%$ \\
\hline W5 - Sawn wood (sawn, chipped, sliced or peeled) / piljena građa & 35 & $72.9 \%$ \\
\hline W6 - Products from planing mill / blanjano drvo & 1 & $2.1 \%$ \\
\hline W7 - Veneer / furnir & 7 & $14.6 \%$ \\
\hline W8 - Wood panels / drvne ploče & 7 & $14.6 \%$ \\
\hline W9 - Engineered wood products / konstrukcijsko drvo & 8 & $16.7 \%$ \\
\hline W10 - Wood package / drvna ambalaža & 6 & $12.5 \%$ \\
\hline W11 - Wood for construction / drvo u graditeljstvu & 14 & $29.2 \%$ \\
\hline W12 - Indoor furniture / namještaj za interijer & 10 & $20.8 \%$ \\
\hline $\begin{array}{l}\text { W13 - Outdoor furniture and gardening / namještaj za eksterijer } i \text { vrtni } \\
\text { namještaj }\end{array}$ & 3 & $6.3 \%$ \\
\hline W15 - Recreational goods / rekreacijski proizvodi & 3 & $6.3 \%$ \\
\hline W18 - Other manufactured wood products / ostali proizvodi od drva & 2 & $4.2 \%$ \\
\hline W19 - Other wood products n.e.c. / ostali neklasificirani drvni proizvodi & 1 & $2.1 \%$ \\
\hline $\mathrm{P}$ - Pulp and paper products / pulpa i proizvodi od papira & 6 & $12.5 \%$ \\
\hline
\end{tabular}


Table 3 Reasons of implementation of FSC certification $(N=52)$

Tablica 3. Razlozi uvođenja FSC certifikata $(N=52)$

\begin{tabular}{|l|c|c|}
\hline \multicolumn{1}{|c|}{ Reasons / Razlozi } & $\begin{array}{c}\text { Number of } \\
\text { answers } \\
\text { Broj } \\
\text { odgovora }\end{array}$ & $\begin{array}{c}\text { Percent of } \\
\text { answers } \\
\text { Postotak } \\
\text { odgovora }\end{array}$ \\
\hline $\begin{array}{l}\text { Customer's requests } \\
\text { zahtjev kupca }\end{array}$ & 48 & $92.3 \%$ \\
\hline $\begin{array}{l}\text { Market demand } \\
\text { potreba tržišta }\end{array}$ & 33 & $63.5 \%$ \\
\hline $\begin{array}{l}\text { Company image } \\
\text { imidž poduzeća }\end{array}$ & 27 & $51.9 \%$ \\
\hline $\begin{array}{l}\text { Environmental awareness } \\
\text { ekološka osviještenost }\end{array}$ & 22 & $42.3 \%$ \\
\hline Promotion / promocija & 10 & $19.2 \%$ \\
\hline $\begin{array}{l}\text { Governmental subsidies } \\
\text { državni poticaji }\end{array}$ & 0 & $0.0 \%$ \\
\hline
\end{tabular}

respondents stated that they did not achieve any benefit from the implementation of FSC certification, but it may be just a matter of their personal perception. If they do not see an increase in sales and income, then they can think that there is no benefit from certification implementation. On the other hand, if they had not implemented FSC certificate, they would probably lose market share, considering that the FSC CoC certification was mainly implemented at their customer request.

High certification costs $(71.2 \%)$ was the highest ranked problem in the implementation of FSC certification. Extensive documentation was the second ranked problem in the implementation of FSC certification $(36.5 \%)$. Revealing of confidential information, lack of understanding of suppliers, frequent changes of standards and resistance of employees were the least ranked problems in the implementation of FSC certification.

Table 4 Benefits of implementation of FSC certification $(N=52)$

Tablica 4. Dobiti od uvođenja FSC certifikata $(N=52)$

\begin{tabular}{|l|c|c|}
\hline \multicolumn{1}{|c|}{ Benefits / Dobiti } & $\begin{array}{c}\text { Number of } \\
\text { answers } \\
\text { Broj } \\
\text { odgovora }\end{array}$ & $\begin{array}{c}\text { Percent of } \\
\text { answers } \\
\text { Postotak } \\
\text { odgovora }\end{array}$ \\
\hline $\begin{array}{l}\text { Keeping existing customers } \\
\text { zadržavanje postojećih kupaca }\end{array}$ & 42 & $80.8 \%$ \\
\hline $\begin{array}{l}\text { Obtaining new customers } \\
\text { pridobivanje novih kupaca }\end{array}$ & 31 & $59.6 \%$ \\
\hline $\begin{array}{l}\text { Increase of competitiveness } \\
\text { povećanje konkurentnosti }\end{array}$ & 26 & $50.0 \%$ \\
\hline $\begin{array}{l}\text { Increase of export } \\
\text { povećanje izvoza }\end{array}$ & 18 & $34.6 \%$ \\
\hline $\begin{array}{l}\text { Increase of company's image } \\
\text { poboljšanje imidža }\end{array}$ & 17 & $32.7 \%$ \\
\hline $\begin{array}{l}\text { Increase of profit } \\
\text { povećanje dobiti }\end{array}$ & 8 & $19.4 \%$ \\
\hline $\begin{array}{l}\text { Increase of sales } \\
\text { povećanje prodaje }\end{array}$ & 6 & $11.5 \%$ \\
\hline None / nije ih bilo & &
\end{tabular}

Table 5 The main problems in implementation of FSC certification $(N=52)$

Tablica 5. Glavni problemi uvođenja FSC certifikata $(N=52)$

\begin{tabular}{|l|c|c|}
\hline \multicolumn{1}{|c|}{ Problems / Problemi } & $\begin{array}{c}\text { Number of } \\
\text { answers } \\
\text { Broj } \\
\text { odgovora }\end{array}$ & $\begin{array}{c}\text { Percent of } \\
\text { answers } \\
\text { Postotak } \\
\text { odgovora }\end{array}$ \\
\hline $\begin{array}{l}\text { High costs of certification } \\
\text { visoki troškovi certifikacije }\end{array}$ & 37 & $71.2 \%$ \\
\hline $\begin{array}{l}\text { Extensive documentation } \\
\text { opsežna dokumentacija }\end{array}$ & 19 & $36.5 \%$ \\
\hline $\begin{array}{l}\text { Revealing of confidential } \\
\text { information / zadiranje u } \\
\text { povjerljive podatke }\end{array}$ & 7 & $13.5 \%$ \\
\hline $\begin{array}{l}\text { Suppliers' lack of understanding } \\
\text { nerazumijevanje dobavljača }\end{array}$ & 7 & $13.5 \%$ \\
\hline $\begin{array}{l}\text { Frequent changes of standards } \\
\text { česte promjene standarda }\end{array}$ & 4 & $7.7 \%$ \\
\hline $\begin{array}{l}\text { Resistance of employees } \\
\text { otpor zaposlenika }\end{array}$ & 3 & $5.8 \%$ \\
\hline
\end{tabular}

\subsection{The impact of FSC certification on financial} performance

4.3. Utjecaj FSC certifikacije na financijsku uspješnost

During 2014, over a quarter of respondents (27\%) achieved annual income higher than 6571 thousand Euros and $31 \%$ of respondents achieved the income between 1314 and 6571 thousand Euros. In 2014, only $2 \%$ of respondents had the annual income lower than 131 thousand Euros.

Only $6.4 \%$ of respondents stated that they have zero income share of certified products. This means that $93.6 \%$ of respondents have been selling FSC certificated products. For most of them, the share of certificated products in total income was between 80 and $100 \%$. This research has shown that the share of certified products in total income of $72.3 \%$ of FSC certificate holders from the Republic of Croatia was more than $20 \%$ during 2014. The majority of respondents were those who had the income above 1314 thousand Euros $(58 \%)$ and had the income share of certified products above $80 \%$ (34\% of respondents). $\chi^{2}$-test is used to establish whether the share of certified products in total income and total income are independent. In 2014, according to $\chi^{2}$-test results, $\left(\chi^{2}=34.15 ; d f=20\right.$; $p=0.03)$, the share of certified products and total income were dependent.

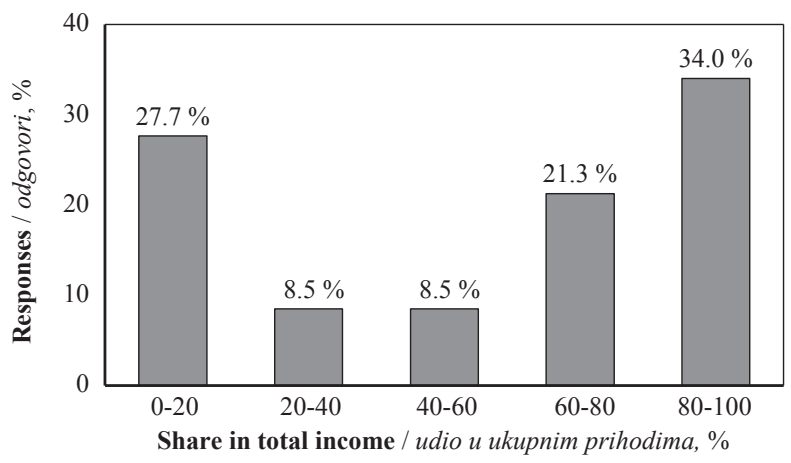

Figure 1 Total income in 2014 (in thousand Euros) Slika 1. Ukupni prihodi u 2014. (u tisućama eura) 


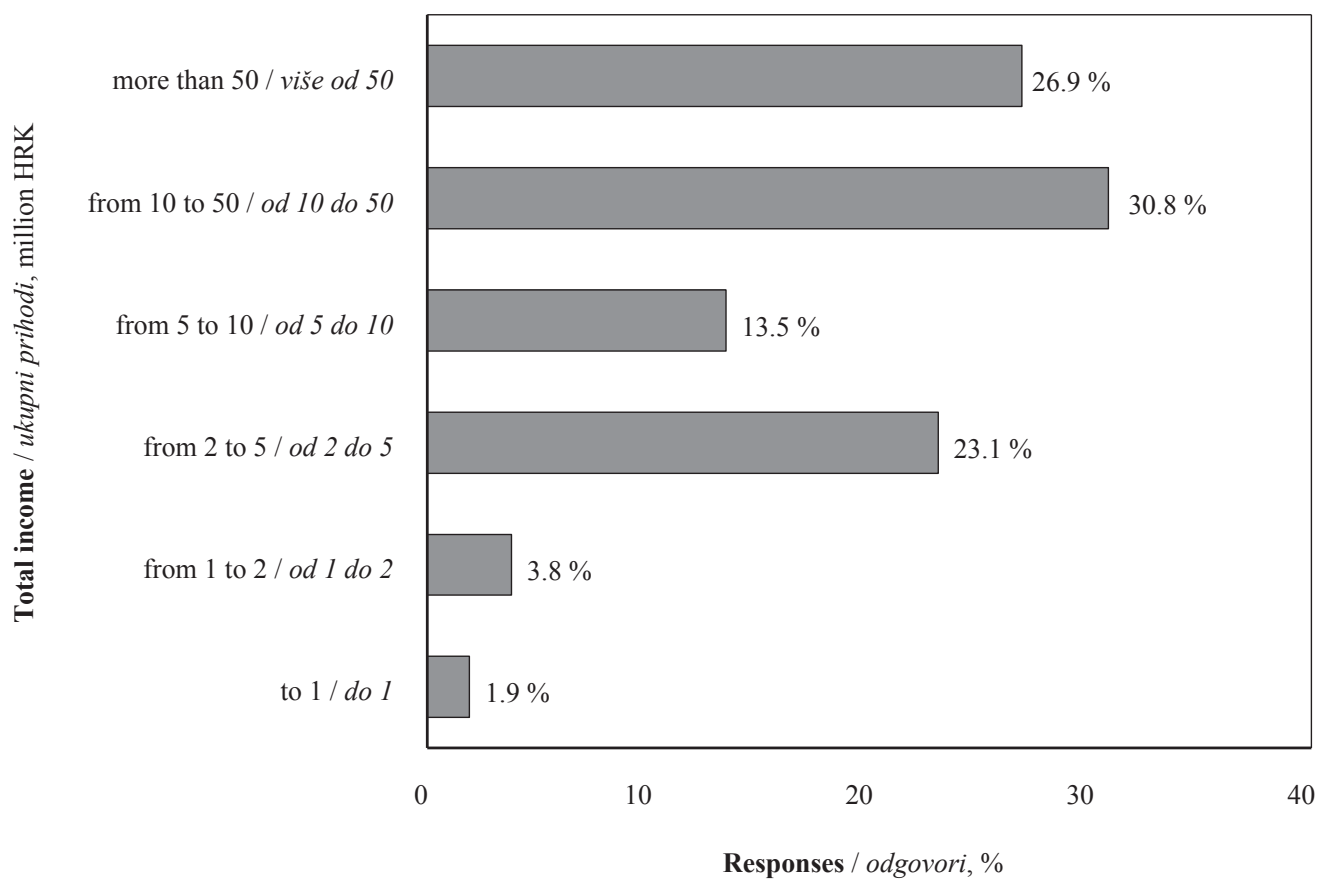

Figure 2 Total income share of certified products in 2014

Slika 2. Udio prihoda od certificiranih proizvoda u 2014.

Respondents were also asked some additional questions regarding financial benefits of FSC certification and certified suppliers. Approximately one third of respondents $(34.6 \%)$ stated that profit increased and $21.2 \%$ of respondents have raised their prices due to FSC certification. Most respondents (75\%) preferred certificated suppliers and $25 \%$ of respondents had problems in finding certified suppliers. The majority of respondents admitted that FSC certification has met their expectations. This is confirmed by the positive answer of maintaining FSC certification among $96 \%$ of respondents. Quite interesting results have been gained among the respondents who stated that they did not have any benefits from FSC certification. Although they did not benefit from the implementation of FSC certification, they unexpectedly declared that would keep the FSC certificate.
Correlation analysis of employee number, income share of certified products, certification duration, and efficiency of total equity (EU) and financial performance profitability ratios (ROA - Return on Assets, ROE - Return on Equity and ROS - Return on Sales) is shown in Table 6. Small positive significant correlations between certification duration and efficiency of total equity and return on assets were established. No significant correlations were established between employee number and profitability ratios. Additionally, no significant correlations between the income share of certified products and profitability ratios were established. Results from correlation matrix suggest that certificate holders from the Republic of Croatia are certificated on customer's request. They have not achieved any additional financial benefit, except keeping customers. Although they failed to achieve additional

Table 6 Correlation matrix

Tablica 6. Matrica korelacija

\begin{tabular}{|l|c|c|c|c|c|c|c|c|}
\hline \multicolumn{2}{|c|}{} & ENo & ICP & CD & EU & ROA & ROE & ROS \\
\cline { 3 - 9 } \multicolumn{2}{|l|}{} & $r$ & $r$ & $r$ & $r$ & $r$ & $r$ & $r$ \\
\hline ENo & $r$ & 1 & 0.050 & 0.255 & 0.191 & -0.107 & -0.132 & 0.002 \\
\hline ICP & $r$ & & 1 & 0.275 & -0.033 & 0.144 & -0.055 & 0.269 \\
\hline CD & $r$ & & & 1 & $0.331^{*}$ & $0.286^{*}$ & -0.092 & 0.189 \\
\hline EU & $r$ & & & & 1 & $0.322^{*}$ & 0.266 & 0.213 \\
\hline ROA & $r$ & & & & & 1 & 0.161 & $0.806^{* *}$ \\
\hline ROE & $r$ & & & & & & 1 & -0.058 \\
\hline ROS & $r$ & & & & & & & 1 \\
\hline
\end{tabular}

ENo - Employees number / broj zaposlenika; ICP - percentage of income from certified products / udio prihoda od certificiranih proizvoda; $\mathrm{CD}$ - certification duration in years / trajanje certifikacije u godinama; EU - Efficiency of total equity / ukupna ekonomičnost poslovanja; ROA

- Return on assets / povrat aktive ; ROE - Return on equity / povrat kapitala; ROS - Return on sales / povrat prodaje; $r$ - Pearson correlation / Pearsonova korelacija.

* Correlation is significant at the 0.05 level. / Korelacija je značajna na razini 0,05 .

** Correlation is significant at the 0.01 level. / Korelacija je značajna na razini 0,01. 
profit due to certification, they plan to maintain FSC certificate in order to survive in the market.

\section{DISCUSSION AND CONCLUSION}

\section{RASPRAVA I ZAKLJUČAK}

Are wood processing companies implementing certification because of their environmental awareness? According to the results of this study, huge expansion of FSC CoC certification in the last decade was customer driven - certification process was initiated by customers. The majority of certificate holders sell their products on EU market (96\%) and numerous sustainable development initiatives among EU member countries have emerged in a form of chain of custody certification. The most frequently stated reason for the introduction of FSC certification is the customer's request $(92.3 \%)$. This certificate is just one of the ways to survive on the market and companies do not see FSC certificate as an instrument of promotion, since the promotion was the second lowest reason for introducing certification. Only $50 \%$ of respondents uses FSC trademarks for promotional purposes.

For the largest number of respondents $(80.8 \%)$ the main benefit of FSC certification is to keep the existing customers. This result is in accordance with their customer driven certification. As other FSC certification benefits, respondents stated other market based benefits - obtaining new customers, increase of competitiveness, increase of export and increase of the company image. For the largest number of respondents, the main problem in the implementation of FSC certification was related to high certification costs (71.2\%).

Although optional, FSC certification for wood industry companies of the Republic of Croatia is not a matter of choice, rather a necessity. Importance of FSC certification can be seen from the fact that $93.6 \%$ of respondents were selling FSC certificated products, almost thirty five respondents $(34.6 \%)$ increased profit due to certification, more than half of respondents have more than $60 \%$ share of certified products in total income and $21.2 \%$ raised prices due to FSC certification. The majority of respondents admitted that FSC certification has met their expectations. This is confirmed by the positive answer of respondents $(96 \%)$ who were willing to maintain FSC certification. Quite interesting results that confirm the importance of FSC certification were obtained among respondents who stated that they did not have any benefits from FSC certification $(11.5 \%)$. Although they pointed out that did not have benefits from the implementation of FSC certification, they also unexpectedly declared that they would keep FSC certificate.

Even though the results of correlation analysis did not show significant influence of FSC certification on all financial performance indicators, the impact of FSC certification on financial performance cannot be neglected. Small significant positive correlations between certification duration and efficiency of total eq- uity and return on assets were established. Although FSC certificate holders did not substantially profit due to certification, FSC certification has enabled them to be competitive, and they had to maintain FSC certificate in order to survive on the market. Results of this study suggest that FSC certification is a precondition for competitiveness for Croatian wood industry companies. These findings are consistent with the findings of Narasimhan et al. (2015), who confirmed that upstream firms (companies at the beginning of supply chain), to which Croatian wood processing companies mostly belong, face coercive pressure from their business customers, and thus might choose to certify even if the benefits of certification are not apparent. Although financial benefits have not been proven significantly, the share of certified products in total revenue is quite significant. Importance of FSC certification for Croatian FSC certificate holders can be presented through the share of certified products in total revenue.

Overall, our findings encourage the implementation of FSC certification. The FSC certification can serve as a signal to customers that the company implements standards which ensure traceability of materials, applies high environmental principles and that it is not included in the trade of illegally harvested timber. However, FSC certification scheme is optional. Many wood processing and furniture manufacturing companies from the Republic of Croatia have implemented FSC standards and this could make it easier for them to provide compliance with mandatory European Union regulations, such as EU Timber Regulation (EUTR 995/2010).

This study is a contribution to the research area of benefits of FSC CoC certification, because besides using subjective benefit measures based on respondent's evaluation, objective measures based on financial reports were also used. Although this study is a significant contribution to the area of chain of custody certification, it is not without limitations. Limitation of this study could be the timeframe of financial performance indicators, so in future research financial performance could be measured over a period of time. Additionally, comparison of financial performance of FSC certificate holders of wood industry and other industries (e.g. printing) could be made.

\section{REFERENCES}

\section{LITERATURA}

1. Bowers, T.; Eastin, I.; Ganguly, I.; Cao, J.; Seol, M., 2012: Forest certification in Asia: The changing marketplace for value-added wood product manufacturers in China and Vietnam. The Forestry Chronicle, 88 (5): 578584. http://dx.doi.org/10.5558/tfc2012-109.

2. Dillman, D. A., 2000: Mail and Internet Surveys: The Tailored Design Method. Second Edition. John Wiley \& Sons, Inc., New York.

3. Fernholz, K.; Kraxner, F.; Novoselov, I.; Oliver, R.; Tissari, J., 2015: Policies shaping forest products markets. Forest products annual market review 2014-2015 (No. 39). United Nations Economic Commission for Europe/ Food and Agriculture Organization of the United Na- 
tions, Forestry and Timber Section, Geneva, Switzerland. http://dx.doi.org/10.18356/cb1665cb-en

4. Hoang, H. T. N.; Hoshino, S.; Hashimoto, S., 2015: Forest stewardship council certificate for a group of planters in Vietnam: SWOT analysis and implications. Journal of Forest Research, 20 (1): 35-42. http://dx.doi.org/10.1007/s10310-014-0472-z.

5. Kozak, R. A.; Cohen, D. H.; Lerner, J.; Bull, G. Q., 2004: Western Canadian consumer attitudes towards certified value-added wood products: an exploratory assessment. Forest Products Journal, 54 (9): 21-24.

6. Lipušček, I.; Bohanec, M.; Oblak, L.; Stirn, L. Z., 2010: A multi-criteria decision-making model for classifying wood products with respect to their impact on environment. The International Journal of Life Cycle Assessment, 15 (4): 359-367. http://dx.doi.org/10.1007/s11367-010-0157-6.

7. Montague, I. B., 2010: Understanding chain-of-custody certification in the Appalachian hardwood region: Primary manufacturers' practices and perceptions. In: S. Fei, J. M. Lhotka, J. W. Stringer, K. W. Gottschalk, \& G. W. Miller (eds.), Proceedings of the $17^{\text {th }}$ Central Hardwood Forest Conference. GTR-NRS-P-78, pp. 607-616.

8. Moore, S. E.; Cubbage, F.; Eicheldinger, C., 2012: Impacts of Forest Stewardship Council (FSC) and Sustainable Forestry Initiative (SFI) forest certification in North America. Journal of Forestry, 110 (2): 79-88. http://dx. doi.org/10.5849/jof.10-050.

9. Narasimhan, R.; Schoenherr, T.; Jacobs, B. W.; Kim, M. K., 2015: The Financial Impact of FSC Certification in the United States: A Contingency Perspective. Decision Sciences, 46 (3): 527-563. http://dx.doi.org/10.1111/deci.12141.

10. Newsom, D.; Bensel, T.; Bahn, V., 2008: Are there economic benefits from Forest Stewardship Council (FSC) certification? An analysis of Pennsylvania state forest timber sales. Rainforest Alliance Working Paper.

11. Oblak L.; Jošt, M., 2011: Methodology for Studying the Ecological Quality of Furniture. Drvna industrija, 62 (3): 171-176. http://dx.doi.org/10.5552/drind.2011.1038.

12. Ozinga, S., 2004: Time to measure the impacts of certification on sustainable forest management. Unasylva, 219 (55): 33-38.

13. Paluš, H.; Kaputa, V., 2009: Survey of attitudes towards forest and chain of custody certification. Drewno, 52 (182): 65-81.

14. Pirc Barčić, A.; Motik, D., 2013: Analysis of Furniture Industry Companies in Croatia. Drvna industrija, 64 (4): 281-291. http://dx.doi.org/10.5552/drind.2013.1305.

15. Perera, P.; Vlosky, R. P., 2006: A history of forest certification. Louisiana Forest Products Development Center, School of Renewable Natural Resources, Louisiana State University Agricultural Center. Working Paper 71.

16. Ratnasingam, J.; Macpherson, T. H.; Ioras, F., 2008: An assessment of Malaysian wooden furniture manufacturers' readiness to embrace chain of custody $(\mathrm{CoC})$ certification. Holz als Roh-und Werkstoff, 66 (5): 339-343. http://dx.doi.org/10.1007/s00107-008-0255-3.
17. Rickenbach, M.; Overdevest, C., 2006: More than markets: assessing Forest Stewardship Council (FSC) certification as a policy tool. Journal of Forestry, 104 (3): 143147.

18. Vidal, N.; Kozak, R.; Cohen, D., 2005: Chain of custody certification: an assessment of the North American solid wood sector. Forest Policy and Economics, 7 (3): 345-355. http://dx.doi.org/10.1016/S1389-9341(03)00071-6.

19. Vlosky, R.; Gazo, R.; Cassens, D.; Perera, P., 2009: Changes in value-added wood product manufacturer perceptions about certification in the United States from 2002 to 2008. Drvna industrija, 60 (2): 89-94.

20. ***Dell Inc., 2015: STATISTICA 12 for MS Windows analytics software.

21. ***FAO, 2015: Global Forest Resources Assessment 2015: How have the world's forests changed? Food and Agriculture Organization of the United Nations. ISBN 978-92-5-108821-0, Rome, Italy.

22. ***FSC-STD-40-004a V2-0, 2011: FSC Product Classification, Forest Stewardship Council. http://www.info. fsc.org (Accessed Apr. 20, 2015).

23. ***FSC-STD-40-004 V2-1, 2011: FSC Standard for Chain of Custody Certification, Forest Stewardship Council. http://www.info.fsc.org (Accessed Apr. 20, 2015).

24. ***EUTR 995/2010 - Regulation (EU) No 995/2010 of the European Parliament and the Council. http://www. eur-lex.europa.eu (Accessed Apr. 20, 2015).

25. ***FSC, 2015: FSC certificate holder database, http:// www.info.fsc.org (Accessed May 20, 2015).

26. *** FSC, 2016: FSC facts and figures, March 1, 2016, https://ic.fsc.org/preview.facts-figures-march2016.a-5663.pdf (Accessed March 20, 2016).

27. ***Hrvatske šume, 2015: Šume u Hrvatskoj, http://www. portal.hrsume.hr (Accessed Aug. 25, 2015).

28. ***IKEA, 2015: IKEA Group Suistainability report FY14, 2014 http://www.ikea.com (Accessed Sept. 29, 2015).

29. ***PEFC, 2015a: PEFC council information register, http://www.pefc.org (Accessed Aug. 23, 2015).

30. ${ }^{* * *}$ PEFC, 2015b: PEFC global statistics: SFM \& COC certification, data: December 2015, http://www.pefc.org/ images/documents/PEFC_Global_Certificates_-_December_2015.pdf (Accessed March 20, 2016).

31. ***RGFI, 2015: Registar godišnjih financijskih izvještaja. Financijska agencija - FINA, http://www.rgfi.fina.hr (Accessed Sep. 20, 2015).

\section{Corresponding address:}

KRISTINA KLARIĆ, PhD

University of Zagreb, Faculty of Forestry

Wood Technology Department

Svetošimunska 25

10002 Zagreb, REPUBLIC OF CROATIA

e-mail: kklaric@sumfak.hr 